\title{
Spectrophotometric End Point Assay for Serum Cystyl Amino Peptidase
}

\author{
M. C. P. Canagaratna \\ Biochemistry Department, Faculty of Medicine, University of Colombo, Colombo, Sri Lanka
}

(Date of receipt: 14 March 1984)

(Date of acceptance: 29 August 1984)

\begin{abstract}
A spectrophotometric end point assay for serum cystyl amino peptidase (CAS) activity was established in this laboratory. The within batch and between batch reproducibility of the method was good, the maximum coefficient of variation being $2.1 \%$ and $3.0 \%$ respectively. The enzyme was found to be stable at $8^{\circ} \mathrm{C}$ there being no loss of activity over a period of 21 days storage at this temperature. The enzyme was found to be inhibited by 5 mM EDTA.
\end{abstract}

\section{Introduction}

Cystyl-aminopeptidase (CAS) is an enzyme produced by the placenta that degrades cystine peptides such as oxytocin and vasopressin. During normal pregnancy, serum CAS activity progressively increases and its level can be used to assess placental function. ${ }^{2}{ }^{3}$ It was decided to establish this useful parameter of placental function in Sri Lanka. Durham ${ }^{1}$ described an end point spectrophotometric method for CAS assay. This paper reports the reproducibility of this assay method. Studies on the stability of the enzyme and its inhibition by EDTA were also carried out and the results are published here.

\section{Materials and Methods}

Blood samples are taken from women on their first visit to the antenatal clinic, to screen for venereal disease. A small aliquot (approximately $1.0 \mathrm{ml}$ ) of each of these samples was sent to the Biochemistry Department of the Faculty of Medicine for CAS assay. Some samples, especially those taken in the latter half of pregnancy, were obtained from in-patients of an obstetric ward. All women included in the study were normal and showed no evidence of any complications such as pre-eclamptic toxaemia or essential hypertension. Subjects who were 'small for dates' were excluded from the study; those with abnormal presentations were, however, included.

Blood samples were allowed to clot and the serum separated after centrifugation in a clinical centrifuge at $1000 \mathrm{rpm}$ and stored at $8^{\circ} \mathrm{C}$ in the refrigerator. The assay was carried out within $24 \mathrm{hrs}$ of sample collection. The assay was carried out in duplicate at a $\mathrm{pH}$ of 7.4 according to the method of Durham. ${ }^{1} \mathrm{~A}$ mixture of $50 \mu \mathrm{l}$ of serum and $1.75 \mathrm{ml}$ of phosphate buffer, $0.1 \mathrm{~mol} / \mathrm{litre}, \mathrm{pH} 7.4$ 
was allowed to equilibrate to a temperature of $37^{\circ} \mathrm{C}$. The reaction was initiated by addition of $0.2 \mathrm{ml}$ of the substrate (S benzyl-L-cysteine- 4 nitroanilide, $6 \mathrm{~m}$. $\mathrm{mol} / \mathrm{litre}$ in acetone/methanol, $10 / 90$ by vol.). The contents of the tubes was mixed on a votary mixer and incubated at $37^{\circ} \mathrm{C}$ for $20 \mathrm{~min}$. The reaction was stopped by the addition of $1 \mathrm{ml}$ of the protein precipitant - $10 \%$ trichloroacetic acid (TCA). The tubes were mixed and centrifuged at $3000 \mathrm{rpm}$ for $5 \mathrm{~min}$. The absorbance at $400 \mathrm{~nm}$ was measured in a Unicam SP 800 spectrophotometer against the reagent blank consisting of $2 \mathrm{ml}$ of buffer $\mathrm{pH} 7.4$ and $1 \mathrm{ml}$ of TCA. The activity in U/litre was read from the calibration curve obtained by diluting the working standard of 4 nitro aniline ( $1 \mathrm{~m} . \mathrm{mol} / \mathrm{litre})$ with buffer $\mathrm{pH} 7.4$ and TCA in the proportions shown in Table 1. ( 1 unit of enzyme activity produces $1 \mu \mathrm{mol}$ of product, 4 nitroaniline, per $\min$ at $37^{\circ} \mathrm{C}$ ).

TABle 1. Protocol for preparation of Calibration Curve

CAS activity U/litre

\begin{tabular}{lcccc}
\hline Reagent & Blank & 100 & 200 & 400 \\
\hline Working standard, ml & 0 & 0.25 & 0.5 & 1.0 \\
Phosphate buffer pH 7.4, ml & 5 & 4.75 & 4.5 & 4.0 \\
Trichloroacetic acid, ml & 2.5 & 2.5 & 2.5 & 2.5 \\
\multicolumn{2}{c}{ Mix and read absorbance at $400 \mathrm{~nm}}$. & \\
\hline
\end{tabular}

The standard curve was prepared by diluting the working standard of 4 nitroaniline ( $1 \mathrm{mmol} / \mathrm{L}$ ) with buffer $\mathrm{pH} 7.4$ and TCA in the proportions shown. $1 \mu$ of enzyme activity produces $1 \mu \mathrm{mmol}$ of product per min at $37^{\circ} \mathrm{C}$.

\subsection{Reproducibility of Asssay}

The within batch reproducibility of the assay was tested by assaying in duplicate, 5 or 6 replicate samples. The between batch reproducibility of the assay was ascertained by testing aliquots of the serum stored at $-20^{\circ} \mathrm{C}$ on 5 separate days.

\subsection{Stability of the enzyme}

A chance observation led to the study of the stability of the enzyme at $8^{\circ} \mathrm{C}$. Aliquots of serum stored at $8^{\circ} \mathrm{C}$ were tested at intervals up to 21 days after collection. 


\subsection{Inhibition by ethylene diaminetetra acetate (disodium salt)-EDTA}

As mosi peptidase enzymes have been shown to be metallo proteins, it was decided to investigate the metal ion requirement of this enzyme. A preliminary step would be to study the effect of a chelating agent such as EDTA. Hence the effect of EDTA was tested by comparing the enzyme activity in the presence of and in the absence of EDTA. This was added to the buffer so that the final concentration in the assay mixture was $5 \mathrm{mM} / \mathrm{L}$.

\section{Results and Discussion}

Table 2 gives the within batch and between batch reproducibility of the assay. It can be seen that the method is highly reproducible as the maximum coefficient of variation observed within a batch was $2.1 \%$ and between batches was $3.0 \%$. These figures are comparable to those observed by Durham. ${ }^{1}$

TABLE 2. Reproducibility of the Assay

\begin{tabular}{|c|c|c|c|}
\hline \multicolumn{4}{|c|}{ Within batch } \\
\hline MeanU/litre & $S . D$. & $\begin{array}{l}\text { C.V. } \\
\%\end{array}$ & Number of observations* \\
\hline 435.3 & 3.0 & 0.7 & 6 \\
\hline 356.4 & 7.4 & 2.1 & 5 \\
\hline 228.6 & 4.2 & 1.8 & 5 \\
\hline 255.3 & 5.0 & 2.0 & 6 \\
\hline \multicolumn{4}{|c|}{ Between Batch } \\
\hline 231.0 & 6.7 & 2.9 & 5 \\
\hline 257.0 & 7.5 & 2.9 & 5 \\
\hline 431.6 & 12.8 & 3.0 & 5 \\
\hline 361.8 & 7.0 & 1.9 & 5 \\
\hline
\end{tabular}

*Each observation is the mean of duplicate values.

The within batch reproducibility of the assay was tested by assaying in duplicate, 5 or 6 replicate samples. The between batch reproducibility of the assay was ascertained by testing aliquots of the serum stored at $-20^{\circ} \mathrm{C}$ on 5 separate days.

Table 3 shows the effect of storage of the enzyme at $8^{\circ} \mathrm{C}$ up to a period of 21 days. The differences in activity on storage were compatible with the between batch variation of the assay. In one instance the C.V. was $6.8 \%$ but the number of observations was small (3) and the enzyme activity was greater on day 21 
compared with day $O$. Hence it can be concluded that the enzyme is remarkably stable at this temperature, thus allowing serum samples to be conveniently stored at this temperature rather than at $-20^{\circ} \mathrm{C}$, while awaiting assay. This feature of serum CAS activity has not been previously reported.

Table 3. Stability of the Enzyme at $8^{\circ} \mathrm{C}$

\begin{tabular}{|c|c|c|c|c|c|}
\hline Sample & $\begin{array}{l}\text { Activity } U / L \\
\text { on Day } O\end{array}$ & $\begin{array}{l}\text { Activity } U / L \\
\text { on Day }(n)\end{array}$ & Mean* & S.D.* & $C . V^{*}$ \\
\hline 1 & 121 & $116(2)$ & - & - & - \\
\hline \multirow[t]{2}{*}{2} & 355 & $370(4)$ & 360.7 & 8.1 & 2.3 \\
\hline & & $357(9)$ & & & \\
\hline \multirow[t]{4}{*}{3} & 223 & $233(3)$ & 231.2 & 6.0 & 2.6 \\
\hline & & $233(5)$ & & & \\
\hline & & $228(8)$ & & & \\
\hline & & $239(9)$ & & & \\
\hline 4 & 209 & $238(19)$ & 226.7 & 15.5 & 6.8 \\
\hline
\end{tabular}

* These were calculated on the basis that storage had no significant effect on enzyme activity.

Aliquots of serum stored at $8^{\circ} \mathrm{C}$ were tested at intervals up to 21 days after collection.

TABle 4. Effect of 5mM EDTA

\begin{tabular}{|c|c|c|}
\hline \multicolumn{2}{|c|}{ Activity $U / L$} & \multirow{2}{*}{$\begin{array}{r}\% \text { Inhibition } \\
\text { by EDTA }\end{array}$} \\
\hline No EDTA & $5 m M E D T A$ & \\
\hline 238 & 91 & 61.8 \\
\hline 491 & 150 & 69.5 \\
\hline 362 & 136 & 62.5 \\
\hline
\end{tabular}

The effect of 5mM EDTA on enzyme activity was ascertained.

Table 4 shows the effect of $5 \mathrm{mM}$ EDTA. This inhibited enzyme activity -to the extent of $60 \%-70 \%$. This suggests that the enzyme has a metal ion cofactor requirement and this aspect is being currently investigated. This aspect of CAS activity has not been previously reported. 


\section{Acknowledgements}

Dr. E. L. Joseph, MBBS (Cey.), FRCOG (London), Consultant De Soyza Maternity Hospital is thanked sincerely for allowing me access to his patients. Miss $\mathrm{K}$ D. Narangoda is thanked for typing the manuscript.

\section{References}

1. Durham, B. H. (1976, Clin. Chem., 22: 79.

2. LeGge, M. (1978). N. Z. J. Med. Lab. Technol. 2: 49.

3. Petrucco, O. M. Cellier, K. \& Fishtall, A. (1973). J. Obstet. Gynaec. BR. Commonwealth. 80: 499. 